\title{
On Methods of Reproduction as Specific Characters.
}

By

\author{
T. A. Stephenson, D.Sc., \\ Zoology Department, University College, London.
}

With 11 Figures in the Text.

\section{CONTENTS.}

PAGE

" reproduction prevalent among Actinians

2. Data relating to the subject collected by W. E. Evans . . . . . . 137

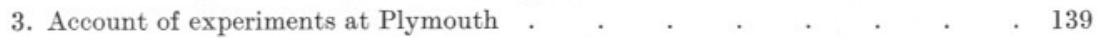

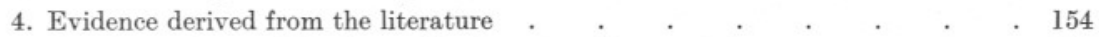

5. The effect of the mode of reproduction upon the morphology . . . . . 157

6. Reproduction in the British species as a whole $\quad . \quad$. . . . . . . 158

7. Discussion . . . . . . . . . . . . . . . . . . 159

8. Summary . . . . . . . . . . . . . . . . . . . . . . . . . 166

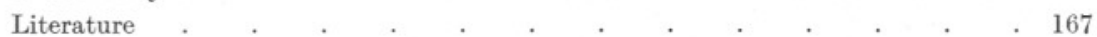

\section{INTRODUCTION.}

THE primary aim of this paper is to show that among certain Actinians investigated, the species are sharply differentiated by their divers methods of reproduction; and to point out that the general question of species is one which is worthy of the attention of experimental biologists. Arguments supporting these contentions will be found in Section 7 .

I should like to make the following acknowledgments. I have received a grant, which has made the work described possible, from the Department of Scientific and Industrial Research. I have received interest and advice from Prof. Watson, and invaluable assistance (detailed below) from Mr. W. Edgar Evans. The whole cultural side of the work was carried out by my wife, who also provided Text-Figs. 2 and 3 , and the sections from which they were drawn. I am very much indebted also to the Plymouth staff and to Miss M. Delap, of Valencia, and Mr. Elmhirst, of Millport, for the collection of the large amount of material required. 


\section{THE METHODS OF REPRODUCTION PREVALENT AMONG ACTINIANS.}

The sea-anemones which have been specially studied for this part of the paper are the following :-

1. Sagartia lacerata (Dalyell).

[S. coccinea of Gosse, but not Actinia coccinea Müller].

2. S. elegans (Dalyell).

[Various colour-varieties were used].

-3. S. anguicoma (Price).

[More usually known in this country as $S$. viduata (Müller). It is not, however, identical with the latter, which is non-British.]

4. S. troglodytes (Price).

[Both varieties of this species were used, the typical form (var. decorata Stephenson) and the var. ornata (Holdsworth)].

5. S. sphyrodeta Gosse.

6. Cereus pedunculatus (Pennant).

[Commonly known as Sagartia bellis (Ellis)].

7. Diadumene cincta Stephenson.

8. D. lucice (Verrill).

[Also known as Sagartia lucia Verrill].

In the above-mentioned species the following methods of reproduction occur.

\section{Oviposition, etc.}

The deposition of either sperms, ova, or both, has been observed in several of the species under consideration; but data relating to this are scanty, and are insufficient to permit us to form any adequate idea as to the extent to which the various species deposit ova in the wild state. Further information is badly needed about the breedingseasons of anemones and about the life-history of their gonads. From the point of view of this paper, however, it may be taken as probable that all or most of the species concerned deposit ova on occasion. The oviparous habit therefore, being general, is not considered in detail here. It could only be of interest to the issue involved if it could be shown that the viviparous species never deposit ova. This, however, is not the case. In Sagartia troglodytes the animal is hermaphrodite, and has been seen to discharge ova and spermatozoa simultaneously, or one a short time after the other; and this probably occurs in nature as well 
as under aquarium conditions, although the species is habitually viviparous. In the other viviparous form, Cereus pedunculatus, the animal is also hermaphrodite, and here I am not aware of cases in which it has been seen to deposit ova. Specimens undergoing irritation have been known to discharge early embryos (observed by Signor Jucci at the Plymouth Laboratory), but this is not, as far as I know, a normal occurrence.

\section{Viviparity (Sagartia troglodytes and Cereus pedunculatus).}

In the viviparous forms, which are sometimes (perhaps always) hermaphrodite, fertilisation is internal, and the embryos develop in the cœlenteron of the parent, achieve their metamorphosis, and are

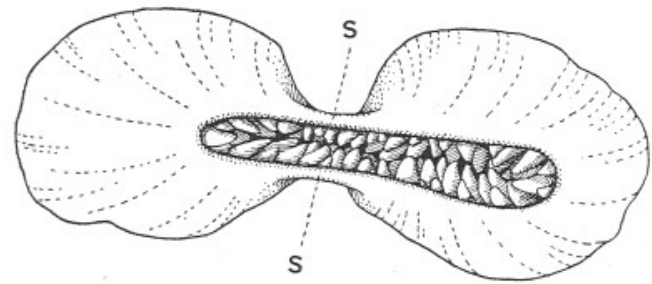

Text-Fig. 1.-Sagartia sphyrodeta. A specimen in the act of dividing into halves. The base, column-wall, and throat have actually ruptured, and the two parts are held together by the sphincter (S) and by part of the oral dise (not visible in the sketch). Enlarged more than 5 diameters.

fully-formed small anemones by the time they escape from the parent. This does not necessarily apply to all the ova of any given specimen; and although fertilisation in the case of the young which are retained is certainly internal, it does not follow that it is effected by spermatozoa belonging to the individual which produced the ova. An anemone with some of its viviparous young* is illustrated in Text-Fig. 5.

\section{Longitudinal Fission (Sagartia sphyrodeta and Diadumene lucia).}

In this method the animal elongates in one direction, the two halves of the base moving away from each other. Rupture results, and each of the halves heals up and forms a new individual. The halves may be equal or unequal in size, but each normally possesses tentacles, so that a complete new set does not have to be regenerated by either half. The fission tears the base and the column-wall, and also involves the throat, in many cases if not always. These statements do not apply to all cases of fission among Actinians, since there are apparently instances in which

* For the sake of brevity the term viviparous young has been used throughout to denote viviparously produced young. 
a gradual separation of parts takes place; but they apply to the normal fissions in the species here dealt with, where the process is one of rupture,

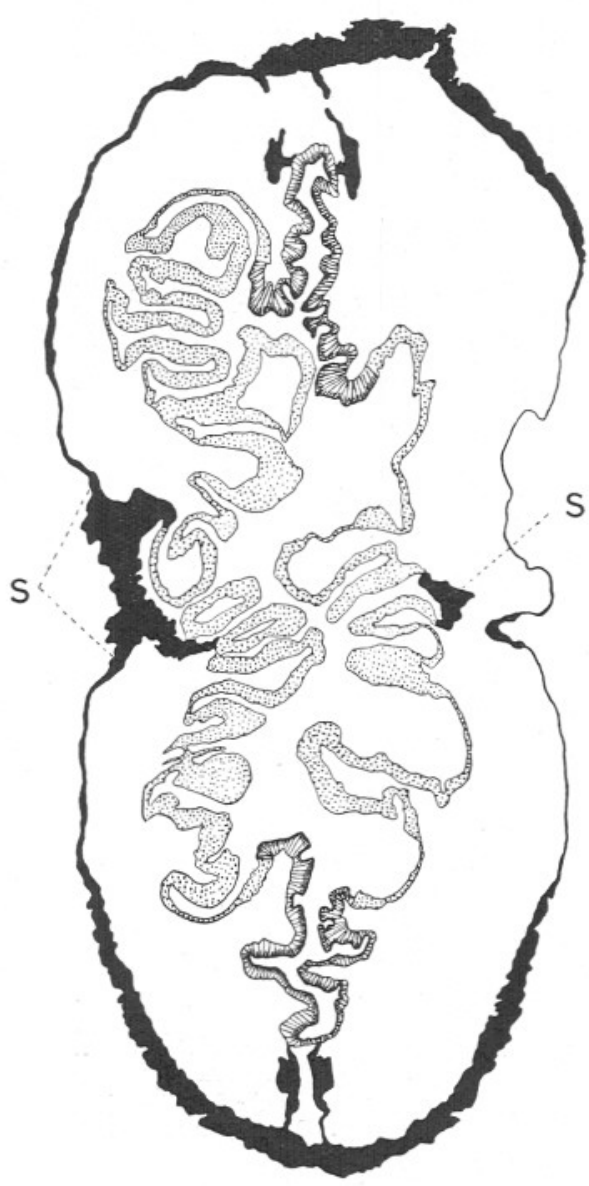

TEXT-Fig. 2.-Sagartia sphyrodeta. A transverse section of the specimen shown in Text-Fig. 1 , after fixation. See text. Column-wall and directive mesenteries black; tentacles and oral disc stippled; throat shaded with strokes. $\mathrm{S}$, sphincter, cut through in two places. All mesenteries are omitted save the directives. and was subsequently sectioned. Two sections from the series are illustrated in Text-Figs. 2 and 3. In the section shown in Fig. 2 the body-wall and oral disc of the two

* In this connection it should be remembered that in Corynactis fission certainly does occur, and may involve the mouth (an observation confirmed by Evans, who has seen fission many times in $C$. viridis). I have tried to show elsewhese $(1921$, p. 510) that Corynactis is probably an aberrant Madrepore which secretes no skeleton, and not an anemone. But this does not affect the question of the typical Madreporaria. 
sides are continuous, and part of the throat is seen in each half. In the other section, Fig. 3 (cut at a lower level than the first), the base, the body-wall, and throat of each half have been torn away completely from the other half.

That fission should occur frequently among the Actiniaria and not among the skeletonbuilding Madreporaria serves only to emphasize the essential difference in tendency between these groups. In the Actiniaria we are dealing with non-colonial organisms which are typically muscular creeping-forms (no other group of the Cœlenterates offers a parallel to this creeping habit of the Actinians), secreting no skeleton, and inclined to divide by means of fission or laceration. In the Madreporaria, on the other hand, it is a question of animals which are frequently colonial, entirely sedentary, nearly always building a skeleton, and reproducing asexually by means of budding of one kind or another, and not by fission; budding is not characteristic of Actiniaria, although cases of it are on record.

In Gonactinia prolifera and Aiptasia couchii, transverse fission takes place; but this is a process of rare occurrence among anemones and not found in the species studied here. In Gonactinia the process is one resembling in some respects the strobilisation of a scyphistoma.

Lastly it may be noted that in

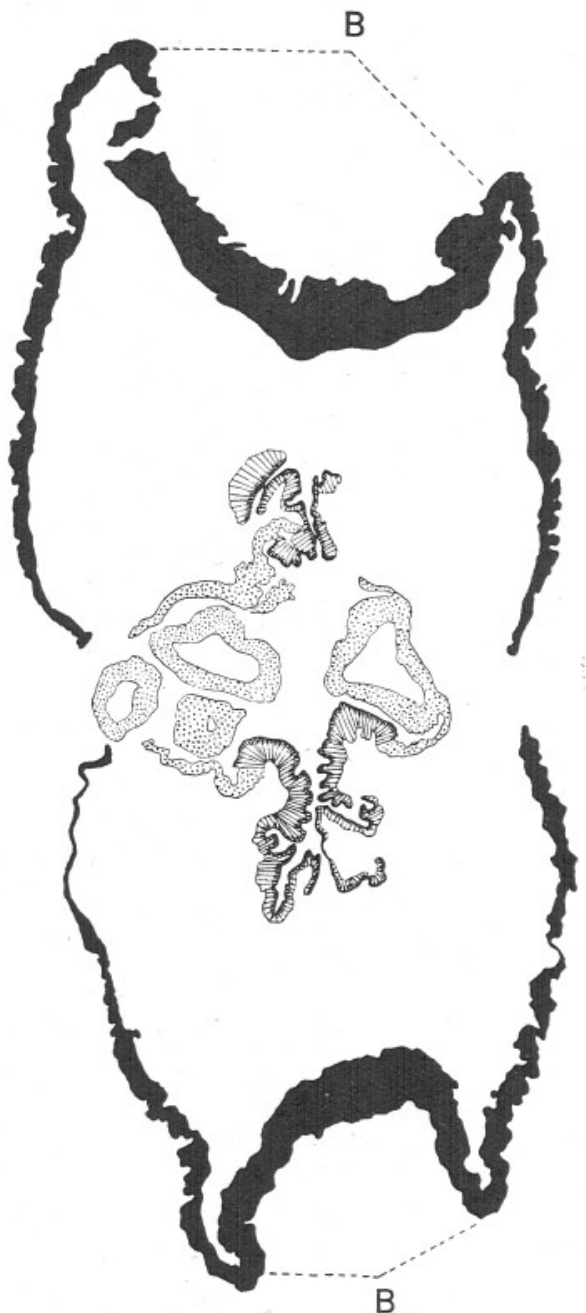

Text-Fig. 3.-A section from the same series as that from which was taken the section shown in Text-Fig. 2; this one is cut at a lower level. See explanation beneath Text-Fig. 2, and also the text. B, basethe animal was somewhat curled up after fixation, so that in the lower part base and column-wall come into the same section on either side. almost any collection of specimens of Sagartia sphyrodeta or Diadumene lucice freshly brought in, it is possible to detect a certain proportion of 
individuals which show unmistakable signs of having recently undergone fission. This is revealed by the presence of a sector of regenerating tissue, of different colour from the rest. A sketch of an expanded specimen which had recently divided is shown in Text-Fig. 4.

\section{Laceration by Tearing (Sagartia elegans and Diadumene cincta).}

In this method no division of the animal occurs so long as it remains stationary (except in the event of its putting out a basal extension and afterwards withdrawing this in such a way that a rupture occurs), but if it begins to creep away there may be left behind a larger or smaller

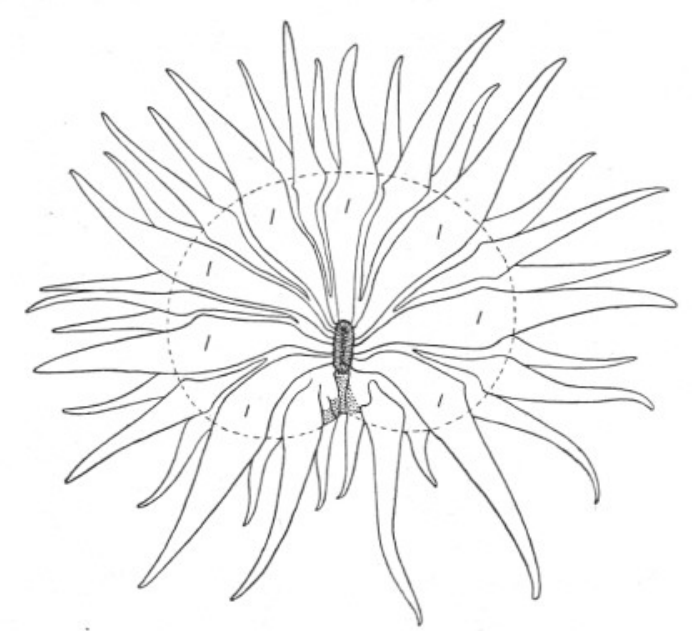

Text-Fig. 4.-Outline of a specimen derived from a recent fission. The shape of the disc (the edge of which is indicated by a dotted line) is modified. The regenerating region (approximately) is stippled. The primary tentacles are marked I. Enlarged about 10 diameters.

fragment, attached to the substratum. The separation of the piece is an actual tear involving a stretching of the region of rupture; it may take place on a perfectly smooth surface, or it may occur when the animal climbs over a rough place or an edge ; in animals kept in finger-bowls a laceration is often produced if the anemone climbs over the edge of the bowl. In my experience the piece torn off is never large enough to contain any portion of the disc and tentacles of the parent, although it includes part of the base, the body-wall, and the lower ends of mesenteries, and may be more than a centimetre in diameter. In Diadumene cincta the animal, after having produced a laceration which has become almost separated from it, occasionally tries to recall the laceration and heal it up again. In the cases observed this resulted in death. 
An example in which six lacerations had separated from a single specimen of Sagartia elegans is illustrated in Text-Fig. 6 .

\section{Laceration by Constriction (Sagartia lacerata).}

Here the parent anemone usually (though not necessarily) remains stationary, and from the expanded edge of its base small capes and islands become constricted off (Text-Fig. 8). These may remain quite close to the parent, or may move away to some distance from it, often remaining connected with it for a time by a thin stolon before complete separation takes place. Here, as in laceration by tearing, the fragments contain base, body-wall, and mesenteries only; and they are usually small, a few millimetres only in diameter, whereas by the other method rather large pieces are sometimes torn off. A specimen from which a number of lacerations had separated is illustrated in Text-Fig. 7.

\section{DATA RELATING TO THE SUBJECT COLLECTED BY W. E. EVANS.}

For some years Mr. W. Edgar Evans, B.Sc., of the Royal Botanic Garden at Edinburgh, has maintained in his house a private marine aquarium of an unusual type. The whole construction and mode of maintenance of his aquarium are excellent, and during the period when Mr. Evans was able to give a considerable amount of attention to it, the health of the animals contained in it was of an extremely high order, such as I have seen equalled nowhere else. For some time now, the tanks have been used almost exclusively for sea-anemones, and all the available British species have been under observation in them at one time or another. Details of the construction and method of maintenance of this aquarium will be found in Discovery, Vol. VII, No. 74, 1926, p. 51.

The methods of reproduction detailed in the last section have been known to naturalists for many years, but the general idea connected with them seems to have been that they are of somewhat erratic occurrence among Actinian species, and that one anemone is as likely to undergo fission, for instance, as another. Although it has been quite clearly understood by certain workers (see p. 154) that some of the methods are characteristic of given species, no special study has been devoted, so far as I am aware, to reproductive methods considered purely as specific characters. While observing the anemones in his collection over a period of several years, Mr. Evans noticed that no one species (save Aiptasia couchii) ever employed more than a single method of reproduction (apart from the deposition of sperms and ova), and some of his notes are given below. The value of his observations lies partly in 
the fact that his aquarium has been one of quite exceptional efficiency, and partly in that, though his records cover but few specimens, many of these were under continuous observation for several years.

The details are as follows. The calculation of times is up to June 27th, 1926. In the majority of cases a separate account of each specimen was kept in an aquarium notebook.

\section{Sagartia troglodytes.}

The records available cover 22 specimens, and 21 were still alive on the date to which the calculations run. Of these, three had been under observation for between 4 and 5 years (two for nearly 5), five for between 3 and 4 years, three for between 2 and 3 years, and the rest for less than a year.

During this time, reproduction by fission or laceration was never seen or even suspected, whilst the production of viviparous young was so normal and frequent in well-fed specimens that it was not as a rule entered in the aquarium notebook, although recorded on certain occasions. Damage to specimens while collecting in the wild usually resulted in the escape of viviparous young. A sample of the entries in the notebook is as follows :-

\begin{tabular}{|c|c|c|c|c|}
\hline $\begin{array}{l}\text { Colour- } \\
\text { Variety. }\end{array}$ & Obtained. & Died. & Locality. & Remarks. \\
\hline ornata & 7.9 .25 & Living & $\begin{array}{l}\text { Valencia, } \\
\text { Co. Kerry }\end{array}$ & $\begin{array}{l}\text { Viviparous young at } \\
\text { intervals. }\end{array}$ \\
\hline scolopacina & 29.5 .22 & 31.5 .24 & $\begin{array}{l}\text { Longniddry, } \\
\text { Forth }\end{array}$ & $\begin{array}{l}\text { Viviparous young } \\
\text { produced }\end{array}$ \\
\hline ornata & 1.4 .23 & Living & Torquay & $\begin{array}{l}\text { Viviparous young } \\
\text { occasionally. }\end{array}$ \\
\hline lilacina & 8.10 .22 & Living & $\begin{array}{l}\text { Joppa, } \\
\text { Forth }\end{array}$ & No reproduction observed. \\
\hline
\end{tabular}

\section{Sagartia elegans.}

The records available cover 14 specimens, and 7 were still alive on the date to which the calculations run. Of these, two were under observation for between 3 and 4 years, five for between 2 and 3 years, four for between 1 and 2 years, and the rest for less than a year. In this species reproduction by laceration was found to be so constant a characteristic of well-fed specimens that again only a certain number of instances were actually entered in the notebook. No healthy specimen was ever kept which did not undergo laceration. Neither fission nor the production of viviparous young was ever observed. A sample of the entries in the notebook is as follows:- 


\begin{tabular}{|c|c|c|c|c|}
\hline Colour- & & & & \\
\hline Variety. & Obtained. & Died. & Locality. & Remarks. \\
\hline ornata* & 2.11 .23 & 12.5 .25 & $\begin{array}{l}\text { Millport, } \\
\text { Clyde }\end{array}$ & $\begin{array}{c}\text { Laceration often. Over } 10 \\
\text { pieces before } 14.12 .24\end{array}$ \\
\hline venusta & 20.1 .25 & Living & $\begin{array}{l}\text { Valencia, } \\
\text { Co. Kerry }\end{array}$ & Laceration occasionally. \\
\hline venusta & 20.9 .22 & 8.25 & Tenby & $\begin{array}{l}\text { Laceration began } 23.12 .22 \text {, } \\
\text { next occurred } 9.1 .23 \text {, } \\
\text { later often. }\end{array}$ \\
\hline ivea & 20.9 .22 & Living & Tenby & Laceration frequently. \\
\hline
\end{tabular}

\section{Sagartia anguicoma.}

The records available cover 6 specimens, and 5 were still alive on the date to which the calculations run. Of these, one was under observation for between 4 and 5 years, one for between 3 and 4 years, the others for less than a year. During this period fission and laceration were never seen or even suspected; production of viviparous young was suspected (not seen) on one occasion, but subsequently definitely disproved.

Beyond the above data general notes are available to the effect that in Cereus pedunculatus viviparous young were produced at all seasons; that in Sagartia sphyrodeta fission was observed at various times, e.g. 10.12.22. and 29.3.25; that in S. lacerata laceration occurred at all seasons; that in Diadumene luciae fission occurred at all seasons if the animals were well fed; and that at $D$. cincta laceration at all seasons was observed.

Further observations by Mr. Evans, on species not specially dealt with in this paper, are given below in Section 6 . For the moment, however, it is enough to say that the results above recorded fit in exactly with those derived from the experiments detailed in the next section.

\section{ACCOUNT OF EXPERIMENTS AT PLYMOUTH.}

I was at first unwilling to agree with the conclusions reached by Evans as a result of his aquarium observations; but subsequently I became much interested in the subject, and decided to undertake some experiments, in the hope of putting the matter upon a more satisfactory basis. I was able to carry out these experiments during five months' residence at Plymouth, January to June, 1927. I regret that I was unable to carry them on for a longer period, because the reproductive processes are slow, and a run of two or three years would have been much better than a few months. Again, the total number of experimental animals (over 400) was not as large as I should have wished, but

\footnotetext{
* Sagartia elegans and S. troglodytes both possess a variety named "ornata."
} 
since many of these had to be accommodated each in a separate fingerbowl, the question of accommodation and maintenance became serious. The time required for keeping clean and feeding individually as many specimens as this is considerable.

The method of experiment was as follows. In the first place it was desired to isolate a number of individuals of each of the species (see p. 148) chosen for experiment, so that a detailed record could be kept of the

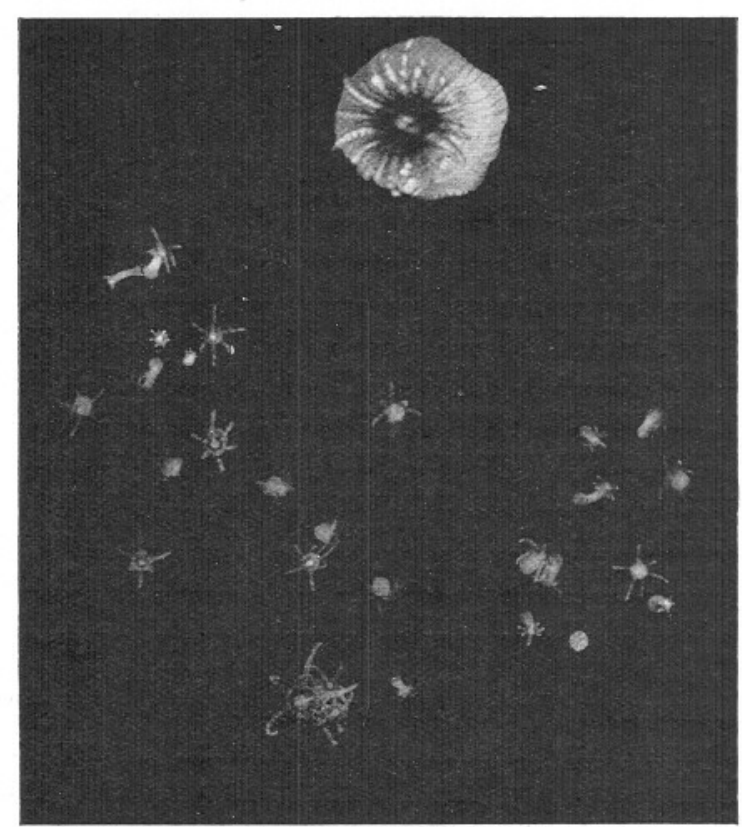

Text-Fig. 5.-From a photograph of a specimen of Bunodactis verrucosa, with a number of viviparous young which it had recently produced. The parent is in a partially contracted condition. Slightly reduced.

activities of each animal. This was done by placing each individual in a separate finger-bowl, and awaiting results. The conditions were kept as uniform as possible for all the species, and the finger-bowls were cleaned and their occupants fed at regular intervals. Great care was taken to provide as adequate aeration as possible, and to keep the animals healthy. The whole of them were inspected daily and notes made of anything which occurred. The general mortality was so low as to be negligible except in two difficult species (S. sphyrodeta and D. lucia) which could not be maintained as satisfactorily as the others with the facilities available. It was necessary to use ordinary tank-water, and this is not 
of the very best quality for delicate species, which also require special conditions in other respects.

In the case of many of the finger-bowls, it was found sufficient to stand them on the slate slabs underneath some of the tanks, and to aerate them for a certain period, daily, by means of a special apparatus which changed the water at the same time.

Other finger-bowls were kept in running water in a tank, the waterlevel being kept below the tops of the finger-bowls so that their isolation

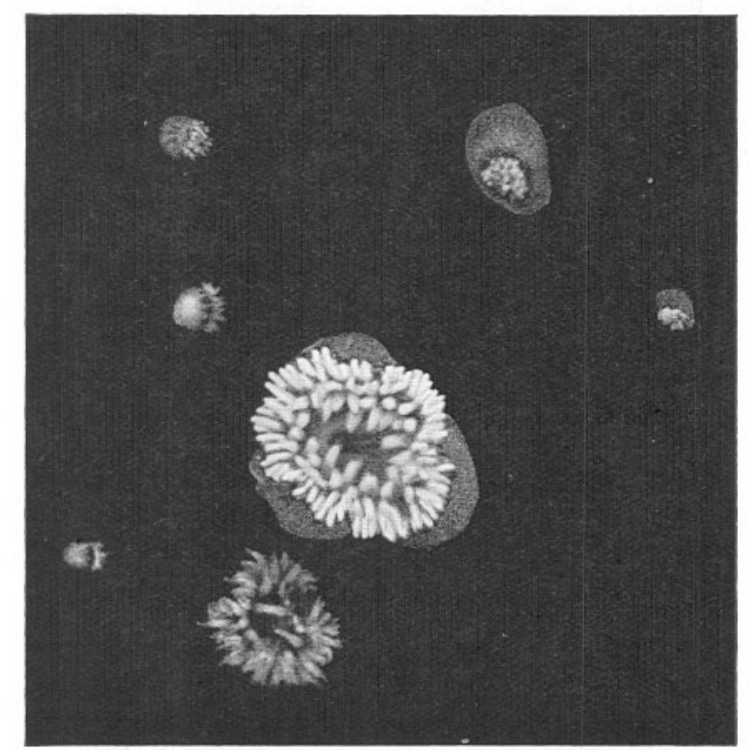

Text-Fig. 6.-From a photograph of a specimen of Sagartia elegans, with six smaller specimens round it. The latter were all produced as lacerations torn away from the parent when it moved from one place to another; all of them have regenerated. Slightly reduced.

was maintained; these were aerated by flooding them once a day. A further number of bowls was kept under water which was in circulation; these were not, therefore, fully isolated from one another (e.g. spermatozoa could escape from one bowl to another), but from the point of view of laceration, fission, and viviparous young, the isolation was adequate.

For a considerable part of the period of experiment, about half the specimens of several species were kept in special finger-bowls which had been entirely lined with a mixture of Portland cement and gravel, sometimes with stones and shells fixed in it. This was in order to provide a rough surface for the animals, with the idea that lacerations might be 
produced more freely on this than on glass. It also gave an excellent opportunity to species which do not normally lacerate, to do so-and thus acted as an additional control. It was found, however, that the kinds which do not lacerate showed not the least tendency to do so on the rough surface; these creatures will glide over edges which would often provide an irresistible opportunity for lacerating, in the other species, without doing so. Moreover, the lacerating species seemed little, if at all,

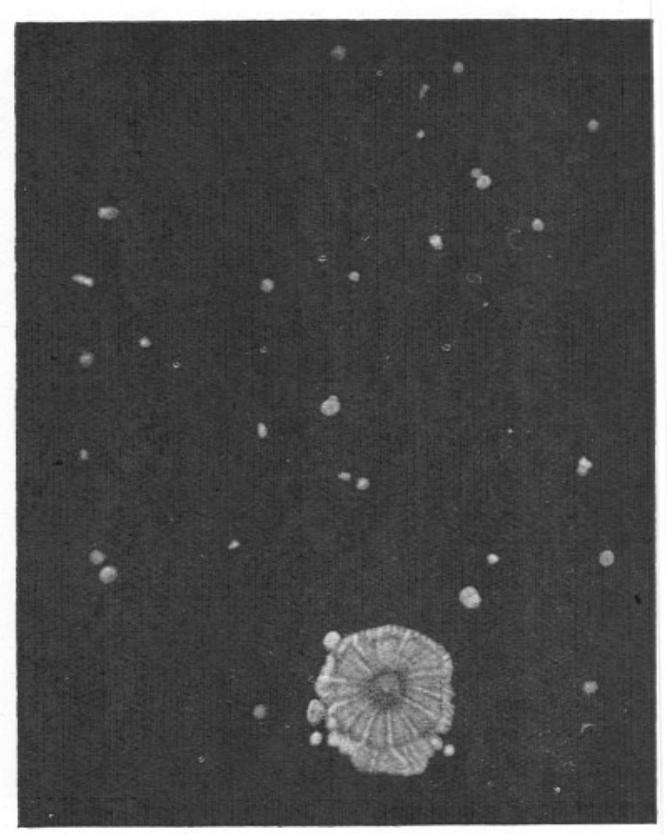

Text-Fig. 7.-From a photograph of a specimen of Sagartia lacerata, also showing a number of small individuals, all produced as lacerations (by the constrictional method) from the one parent. Both the parent and such of the young as possessed them had withdrawn their tentacles, as is usual in this species when exposed to daylight. Slightly reduced.

more inclined to tear themselves on the rough surface than on the smooth. These cement bowls are useful for various purposes, but have to be soaked first in fresh and later in sea-water, and scrubbed free from the crystals which form on the cement, for some time before they are fit for use. In the detailed records of the experiments no distinction is made between cases in which the animals were in glass bowls for the whole period, and those in which they were at first in glass bowls and later in cement ones; because it was found that the change had no effect on 
the essential conditions of the experiment. Most of the cement bowls were kept under circulation.

In the second place it was desired to ascertain whether, in species which do not reproduce by any asexual method under natural conditions, portions cut off artificially would regenerate as readily as in the case of species which lacerate of their own accord. For this purpose four species were chosen, two belonging to each category. Prior to each operation, a healthy adult anemone was allowed to settle comfortably in a finger

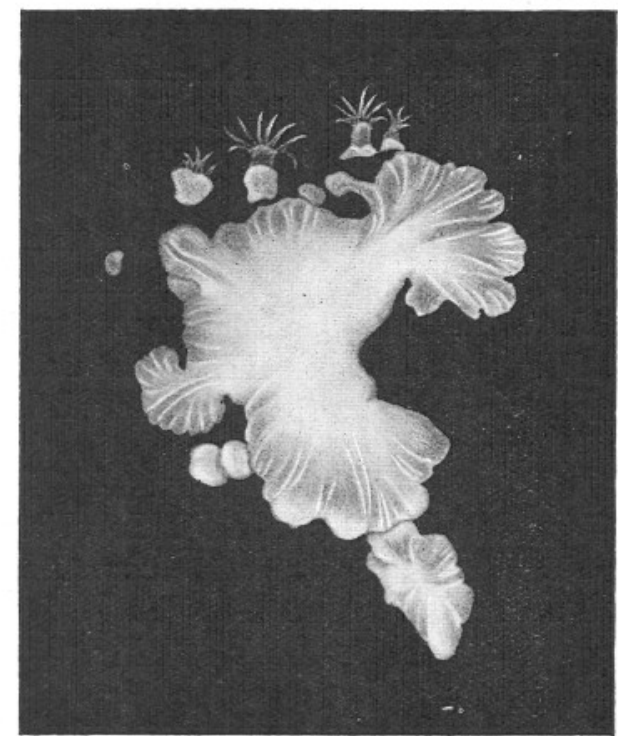

Text-Frg. 8.-A specimen of Sagartia lacerata which had attached itself to glass; viewed through the glass from below the base. Several pieces are becoming or have become separated from the edge of the base, and in four of these tentacles are visible. Slightly enlarged.

bowl, or on a glass slide; when it had become firmly attached, small portions were separated from the edge of its base by tangential cuts with a small, sharp, sterilised scalpel. After the cuts had been made the parent anemone was removed and the glass cleaned, this leaving behind the separated pieces attached to the bowl. The bowls containing the pieces were kept under circulation in a tank, and the pieces allowed to regenerate. Plymouth tank-water is not an ideal medium for such experiments, because it contains a soft sediment which settles continually in the bowls and on the regenerating pieces, so that it is not easy to keep them sufficiently clean; if the sediment is allowed to 
accumulate for too long the pieces die. Nevertheless, the general results were satisfactory. The details are as follows :-

\section{A. Experiments on the Natural Methods of Reproduction.*}

\section{Sagartia elegans.}

\section{Experiment 1.}

32 specimens were used (30 to begin with, the other two to replace specimens which died). The duration of the experiment was 21 weeks and 5 days (January 13 th to June 14 th), and during that period 52 lacerations were produced, all by the tearing method. The number of specimens which underwent laceration was $21(65 \cdot 6 \%$ of the whole number).

\section{Experiment 2.}

26 specimens were used ( 25 to begin with, the other one to replace a specimen which died). The duration of the experiment was 14 weeks and 2 days (March 6th to June 14th), and during that period 8 lacerations were produced, all by the tearing method. The number of specimens which underwent laceration was $5(19 \cdot 2 \%$ of the whole number).

\section{Other data.}

From about 30 specimens which were not included in the main experiments, but were kept in other vessels, 20 lacerations were produced during the period of the main experiments.

\section{Summary.}

From over 80 specimens of $S$. elegans there were produced 80 lacerations during the course of the experiments; by no means every specimen produced a laceration during this period, but some specimens produced more than one, so that the total number produced averages about one laceration to each individual used.

\section{Sagartia lacerata.}

\section{Experiment 1 .}

15 specimens were used. The duration of the experiment was 20 weeks and 5 days (January 15th to June 9th), and during that period 172 lacerations were produced, all by the constrictional method. All the specimens underwent laceration, the respective number of lacerations produced by the different individuals being as follows: $1,6,11,8,13$, $15,9,28,8,13,40,1,8,1,7$.

* In this account of the experiments it is to be understood that no method of reproduction occurred in any experiment except the one recorded. 


\section{Experiment 2.}

21 specimens were used. In this case all were contained in a single bowl, and the lacerations were removed as formed. Between February 11 th and June 14th (17 weeks and 4 days), 116 lacerations were produced. One adult was removed on April 19th.

\section{Summary.}

From 36 specimens of $S$. lacerata there were produced 288 lacerations in the course of the experiments.

\section{Sagartia sphyrodeta.}

\section{Experiment 1 .}

27 specimens were used (21 to begin with, 6 to replace specimens which died). Other specimens died before the end of the experiment, and were not replaced-total deaths 12 . The duration of the experiment was 21 weeks (January 12th to June 8th), and during that time 7 specimens underwent longitudinal fission, two of these being further subdivisions of the halves resulting from a previous fission.

\section{Experiment 2 .}

11 specimens were used ( 7 to begin with, 2 to replace specimens which died, and 2 added later). Other specimens died before the end of the experiment, and were not replaced-total deaths 5. The duration of the experiment was 16 weeks and 1 day (February 15th to June 8th), and during that period no fission occurred.

\section{Other data.}

Two specimens not included in the above experiments were observed to undergo longitudinal fission, and from among other specimens collected 9 showed unmistakable evidence of having recently undergone fission, the regeneration-zone being clearly marked.

\section{Summary.}

Among the 38 experimental specimens 7 cases of fission occurred during the period of observation; two other cases were observed in specimens outside the experiments. Nine further specimens collected had recently undergone fission.

\section{Sagartia troglodytes var. decorata.}

\section{Experiment 1.}

16 specimens were used (15 to begin with, one to replace a specimen which escaped). The duration of the experiment was 20 weeks and 6 days (January 19th to June 14th), and during that period none of the 
specimens underwent any form of asexual reproduction, nor did any of them produce viviparous young. The gonads appeared to be ripening towards the end of the experiment, so that the time for the production of viviparous young in these specimens would be later in the year. This is the only negative result reached which should have been positive; for there is ample evidence from other quarters to show that this form is viviparous.

\section{Sagartia troglodytes var. ornata.}

\section{Experiment 1 .}

15 specimens were used. The duration of the experiment was 21 weeks and 3 days (January 15th to June 14th), and during that period 20 viviparous young were produced. These were produced by 6 of the specimens, the rest $(60 \%$ of the whole number) producing nothing.

\section{Experiment 2.}

In this case 48 specimens were divided out among three vessels. Between February 2nd and April 9th (9 weeks and 3 days) they produced among them 56 viviparous young.

Other data.

7 viviparous young were produced by specimens received from Millport on April 24th-produced on April 25th.

\section{Summary.}

63 specimens produced among them 76 viviparous young during the period of observation. Seven other viviparous young were produced by further specimens (number unknown) of the species, on April 25th. The period of the experiments did not cover the prolific season of production.

VI. Sagartia anguicoma ("viduata").

\section{Experiment 1.}

15 specimens were used. The duration of the experiment was 21 weeks and 3 days (January 15th to June 14th), during which time no asexual reproduction of any kind occurred, nor were any viviparous young produced.

VII. Cereus pedunculatus (Sagartia bellis).

\section{Experiment 1.}

15 specimens were used. The duration of the experiment was 21 weeks and 3 days (January 15th to June 14th), during which time 110 viviparous young were produced. These young were produced by 11 of the 
parents, the other four producing none. The numbers produced by the 11 adults in question were respectively $19,2,11,16,6,37,3,5,1,3$, and 7 .

\section{Experiment 2.}

In this case 24 specimens were kept together in a tank, and the young removed as born. Between March 26th and June 16th (11 weeks and 5 days), 104 viviparous young were produced.

\section{Other data.}

One specimen not in either of the above experiments produced 12 viviparous young between April 19th and June 14th.

\section{Summary.}

40 specimens produced among them 226 young during the period of observation.

\section{Diadumene cincta.}

\section{Experiment 1.}

16 specimens were used ( 15 to begin with and one to replace a specimen which died). These were at first placed each in a separate finger-bowl, as usual, but later on some of them were transferred to a single square dish containing stones and gravel, so that they could be given a type of aeration which suited them better. The duration of the experiment was 21 weeks and 4 days (January 14 th to June 14th), and during that time 8 lacerations were produced, all by the tearing method. In two cases the animal tried to recall the laceration before it had quite separated off; this resulted in death.

Other data.

A specimen outside the above experiment produced a laceration by the tearing method on March 22nd.

\section{Diadumene ("Sagartia") lucia.}

\section{Experiment 1.}

We were unable to obtain good material for this experiment. The few specimens available were all very small, and not in first-rate condition. This accounts for the poor result. Moreover, such small specimens (a few millimetres only in diameter) are difficult to keep, under the conditions of the experiment, and although 22 specimens in all were used (15 to begin with, the others to replace those which died), only 3 were still alive after May 22nd. The experiment started January 12th-20th. During the experiment 5 specimens underwent longitudinal fission. 


\section{Other data.}

A specimen collected on April 19th had recently undergone fission.

The net result of the above experiments and observations is summarised in the following table, which shows the total number of new animals produced by any method in each of the species used, within the period of observation (about 21 weeks). In the cases of S. sphyrodeta and D. lucice the collected specimens which had recently undergone fission are included. The result is discussed on page 159 .

\begin{tabular}{|c|c|c|c|c|}
\hline Species. & Fission. & $\begin{array}{l}\text { Laceration by } \\
\text { Tearing. }\end{array}$ & $\begin{array}{l}\text { Laceration by } \\
\text { Constriction. }\end{array}$ & $\begin{array}{l}\text { Viviparous } \\
\text { Young. }\end{array}$ \\
\hline Sagartia elegans & - & 80 & - & - \\
\hline S. lacerata & - & - & 288 & - \\
\hline S. sphyrodeta & 18 & - & - & -- \\
\hline S. troglodytes & & & & \\
\hline $\begin{array}{l}\text { var. decorata } \\
\text { S. troglodytes }\end{array}$ & 一 & - & - & - \\
\hline var. ornata & - & - & - & 83 \\
\hline S. anguicoma & - & - & 一 & - \\
\hline Cereus pedunculatus & - & 一 & & 226 \\
\hline Diadumene cincta & - & 9 & & - \\
\hline D. luciæ & 6 & - & - & 一 \\
\hline
\end{tabular}

\section{B. Experiments in Artificial Laceration.}

The results of these experiments are summarised in the table on the opposite page.

The pieces were not all cut off on the same date, because it was impossible to obtain enough material in suitable condition for operation, at any single time early in the period of experimentation. The experiments therefore lasted longer for some pieces than for others, the minimum time being 6 weeks and 5 days; but it must be remembered that the experiment for any given piece may be regarded as being over when that piece has attained full development, so that in this sense some of the experiments were complete long before the end of the whole period of experimentation. The variation in date of starting makes no essential difference to the result, because the highest mortality normally occurs shortly after the operation, and it may be taken that if an amputation survived for the minimum period mentioned it would, in the ordinary course of events, ultimately become fully developed even if it had not already done so by the end of the experimental period. 


\begin{tabular}{|c|c|c|c|c|c|c|c|c|c|}
\hline \multirow{2}{*}{ Species. } & \multirow{2}{*}{$\begin{array}{l}\text { Number } \\
\text { of } \\
\text { specimens } \\
\text { used. }\end{array}$} & \multirow{2}{*}{$\begin{array}{l}\text { Number } \\
\text { of } \\
\text { pieces } \\
\text { cut off. }\end{array}$} & \multirow{2}{*}{$\begin{array}{l}\text { Number which } \\
\text { survived } \\
\text { until end of } \\
\text { experiment. }\end{array}$} & \multicolumn{3}{|c|}{$\begin{array}{c}\text { Time taken to regenerate } \\
\text { tentacles. }\end{array}$} & \multicolumn{3}{|c|}{$\begin{array}{l}\text { Time taken to acquire } \\
\text { mouth and disc } \\
\text { as well as tentacles. }\end{array}$} \\
\hline & & & & Minimum. & Maximum. & Average. & Minimum. & Maximum. & Average. \\
\hline \multirow[t]{2}{*}{ Sagartia elegans } & 23 & 60 & $\begin{array}{c}55 \\
(91 \cdot 7 \%)\end{array}$ & $\begin{array}{c}2 \text { weeks } \\
1 \text { day }\end{array}$ & $\begin{array}{c}9 \text { weeks } \\
1 \text { day }\end{array}$ & $\begin{array}{r}4 \text { weeks } \\
6 \text { days } \\
54\end{array}$ & $\begin{array}{r}4 \text { weeks } \\
5 \text { days }\end{array}$ & $\begin{array}{c}14 \text { weeks } \\
6 \text { days }\end{array}$ & $\begin{array}{r}8 \text { weeks } \\
5 \text { days } \\
36\end{array}$ \\
\hline & & & & \multicolumn{3}{|c|}{5 only achieved tentacles } & \multirow{2}{*}{\multicolumn{3}{|c|}{$\begin{array}{c}2 \text { only achieved mouths, } \\
\text { they were perfect } \\
\text { after } 12 \text { weeks } 4 \text { days. }\end{array}$}} \\
\hline $\begin{array}{l}\text { Sagartia troglodytes } \\
\text { var. decorata }\end{array}$ & 21 & 76 & $\begin{array}{c}22 \\
(28 \cdot 9 \%) \\
32 \text { made some } \\
\text { attempt at re- } \\
\text { generation, but } \\
2 \text { only became } \\
\text { fully developed }\end{array}$ & $\begin{array}{l}5 \text { weeks } \\
3 \text { days }\end{array}$ & $\begin{array}{l}8 \text { weeks } \\
4 \text { days }\end{array}$ & $\begin{array}{l}7 \text { weeks } \\
3 \text { days }\end{array}$ & & & \\
\hline Sagartia anguicoma & 18 & 67 & $\begin{array}{c}39 \\
(58 \cdot 2 \%)\end{array}$ & $\begin{array}{c}3 \text { weeks } \\
2 \text { days }\end{array}$ & $\begin{array}{l}13 \text { weeks } \\
3 \text { days }\end{array}$ & $\begin{array}{l}8 \text { weeks } \\
4 \text { days } \\
36\end{array}$ & $\begin{array}{l}6 \text { weeks } \\
4 \text { days }\end{array}$ & $\begin{array}{l}15 \text { weeks } \\
5 \text { days }\end{array}$ & $\begin{array}{r}11 \text { weeks } \\
5 \text { days } \\
22\end{array}$ \\
\hline $\begin{array}{l}\text { Sagartia lacerata } \\
\text { (summary of all } \\
\text { experiments) }\end{array}$ & $\begin{array}{l}\text { A con- } \\
\text { siderable } \\
\text { number } \\
\text { (not } \\
\text { exactly } \\
\text { recorded) }\end{array}$ & 62 & $\begin{array}{c}51 \\
(82 \cdot 3 \%)\end{array}$ & $\begin{array}{l}3 \text { weeks } \\
2 \text { days }\end{array}$ & $\begin{array}{l}13 \text { weeks } \\
2 \text { days }\end{array}$ & 10 weeks & $\begin{array}{l}4 \text { weeks } \\
3 \text { days }\end{array}$ & $\begin{array}{l}17 \text { weeks } \\
1 \text { day }\end{array}$ & $\begin{array}{l}10 \text { weeks } \\
3 \text { days }\end{array}$ \\
\hline $\begin{array}{l}\text { Sagartia lacerata } \\
\text { (the best experi- } \\
\text { ment only) }\end{array}$ & Several & 20 & $\begin{array}{c}20 \\
(100 \%)\end{array}$ & $\begin{array}{l}3 \text { weeks } \\
2 \text { days }\end{array}$ & $\begin{array}{l}3 \text { weeks } \\
2 \text { days }\end{array}$ & $\begin{array}{l}3 \text { weeks } \\
2 \text { days } \\
4\end{array}$ & $\begin{array}{l}4 \text { weeks } \\
3 \text { days }\end{array}$ & $\begin{array}{r}8 \text { weeks } \\
2 \text { days }\end{array}$ & $\begin{array}{l}5 \text { weeks } \\
5 \text { days } \\
4\end{array}$ \\
\hline
\end{tabular}

In the above table the number in the lower right-hand corner of each of the rectangles containing an average, represents the number of pieces from which the average was calculated. There is no implication that specimens not included in this number failed to regenerate properly - the implication is that the time in which they regenerated could not be determined. 
The essential part of these results may be better understood by their concentration in a further table as follows :--

$\begin{array}{ccccc}\text { Number } & \begin{array}{c}\text { Percentage } \\ \text { of } \\ \text { pieces }\end{array} & \begin{array}{c}\text { reared } \\ \text { (to nearest } \\ \text { whole } \\ \text { cut off. }\end{array} & \begin{array}{c}\text { Average time } \\ \text { in which } \\ \text { tentacles } \\ \text { number). }\end{array} & \begin{array}{c}\text { Average time } \\ \text { in which } \\ \text { animal became }\end{array} \\ & & \text { weregenerated. } & \text { fully formed. }\end{array}$

Sagartia elegans

$92 \%$

4 weeks 6 days

8 weeks 5 days.

S. troglodytes

var. decorata

$29 \%$ lived 7 weeks 3 days 12 weeks 4 days. $3 \%$ became

fully formed

S. anguicoma

$$
58 \%
$$

8 weeks 4 days

11 weeks 5 days.

\section{S. lacerata (one experiment only)}

3 weeks 2 days 5 weeks 5 days.

These tables call for further comment. The records of the times taken for regeneration of tentacles and for the regeneration of the whole animal cannot be taken too seriously, because they are approximate, and may be partly misleading; but they are recorded for what they are worth.

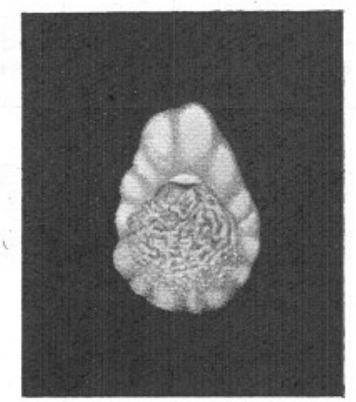

Text-Fig. 9.-A specimen of Sagartia anguicoma, produced from a small piece cut from the edge of the base of a large specimen. Regeneration is well advanced, and the regenerated tissue is clearly distinguishable from the old tissue as a pale crescent. Tentacles were present, but were retracted at the time when the sketch was made. Magnified nearly 5 diameters.

In these regenerating pieces (except in the case of Sagartia troglodytes, where the regenerating tentacles are non-retractile) the tentacles are usually retractile from the beginning, and consequently may be hidden from view at the time of the periodic observations. This means that it is very difficult to tell the exact date upon 
which tentacles or mouth first came into being in any given piece, and that data could not be obtained for all the pieces under observation. On the other hand, if a specimen is contracted at the time of one observation it is often expanded the next time, so that in the majority of cases the figure gained probably gives an approximation to the truth, allowing a fairly wide margin of error. The net result is that the minimum times given are probably the most valuable; the averages are probably too high; and the maximum times mean very little, since they probably represent the individuals which were either contracted most often or were abnormally backward in development. Notwithstanding the above, I think the data are sufficiently satisfactory to make valid the conclusion

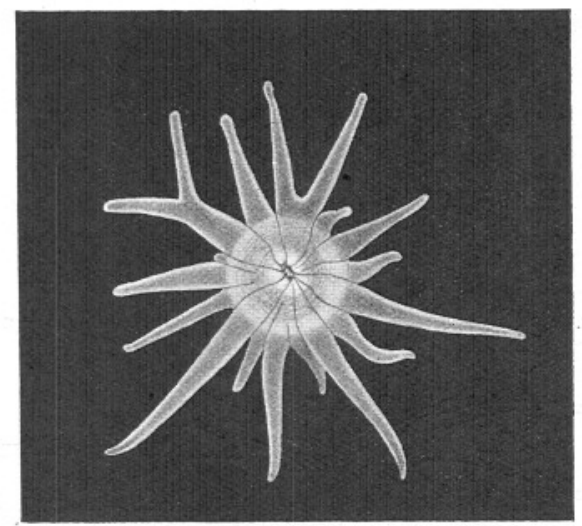

Text-Fig. 10.-One of the two specimens of Sagartia troglodytes which regenerated fully from an artificially separated basal fragment. One tentacle is forked at the base, another higher up. Enlarged about 12 diameters.

that under the conditions of the experiment pieces of $S$. lacerata and S. elegans (the forms which lacerate naturally) regenerated more rapidly, in the main, than those of $S$. troglodytes and $S$. anguicoma.

The more important side of the result, however, is that upon which the information is precise, i.e. the percentage of pieces which were able to regenerate into fully-formed animals in the various species. Here a separate note on each form will be advisable.

\section{Sagartia elegans.}

In this species the pieces regenerate easily and often rapidly. The percentage reared $(92 \%)$ is actually too low, since the remaining specimens (5) were mostly lost, and did not actually die. One can expect to rear something like $100 \%$ of any good batch of pieces detached from individuals of this species. 


\section{S. troglodytes.}

The remarkable fact here emerges, that of 76 pieces, only 2 came to maturity (one of these is illustrated in Text-Fig. 10) ; 32 pieces made some attempt at regeneration, but in only 5 did this reach even the grade of tentacles. The regeneration was slow and obviously difficult, and often abnormal and imperfect. It is quite clear that the pieces did not regenerate at all easily under the conditions provided. This may be accounted for as follows. In the rearing of basal fragments, the probability of success depends on three factors: (1) the firmness with which the piece is attached to the glass, (2) the amount of mucus which it secretes,

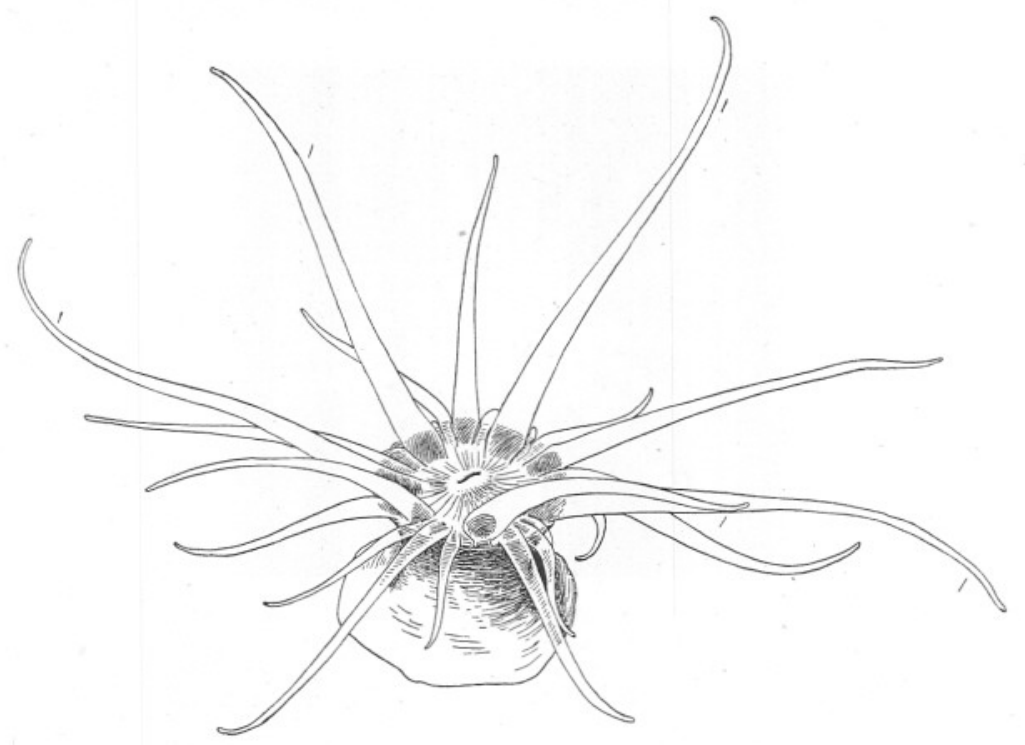

Text-Fig. 11.-A fully regenerated specimen of Sagartia anguicoma, produced from an artificially separated basal fragment. The primary tentacles are marked I. Magnified about 9 diameters.

and (3) the degree to which it can be kept clean. In Sagartia the degree of firmness with which the animal adheres to foreign surfaces varies distinctly according to species, although individual exceptions may always be found to this rule. In the main, for instance, S. troglodytes adheres much less tightly than do $S$. anguicoma or S. elegans. This means that pieces cut away from troglodytes are often but lightly attached, or may come loose altogether; and in rearing pieces it is a rule that mortality among loose or nearly loose fragments is very much higher than among such as are well attached. Again, the amount and quality of the daily secretion of mucus in Sagartia varies, and this variation, of course, occurs in the fragments. S. troglodytes secretes a tougher and 
more tenacious mucus than do $S$. anguicoma and $S$. elegans, and in the case of the fragments this often forms a dense cap or ring round the piece, from which the fragment cannot free itself, and this cap forms an admirable site for the accumulation of sediment and bacteria. To anyone who has reared such pieces these reasons are adequate to explain the difficulty of rearing troglodytes; but in addition it seems in itself a delicate species, and by watching the course of regeneration one receives the impression that its regenerative ability is not strong.

\section{S. anguicoma.}

In this case, although the proportion of pieces reared $(58 \%)$ was lower than in $S$. elegans, it was evident that the species possesses strong regenerative ability, and the pieces usually regenerate well and cleanly, although with less certainty than do those of elegans. This is doubtless partly due to the fact that they usually adhere very firmly, and secrete mucus of a less offensive nature than that of troglodytes; but they seem to be also stronger and of a firmer texture in themselves. A regenerating fragment of this species is illustrated in Text-Fig. 9, and an expanded specimen fully regenerated in Text-Fig. 11.

\section{S. lacerata.}

In this species the result should theoretically be as good as those in S. elegans, since S. lacerata fragments more freely in nature than any other form. In fact, however, except in the best experiment, they fell below expectation; but it is possible to account reasonably for this. In the earlier experiments, most of the pieces cut off were very small (S. lacerata is usually a small species, and they were mostly smaller than in the other species used), and did not regenerate very well. I believe this may be due to the fact that laceration in this species, when it occurs naturally, is a gradual process of constriction, and does not involve a large open wound as does the ripping incurred by $S$. elegans. In a small piece cut off suddenly, on the other hand, a wide open wound is involved, and this does not seem to suit the species. Consequently, after this had been realised, 20 pieces of slightly larger average size, but still not more than a few millimetres in diameter, were cut off from a set of adults, and all of these regenerated and survived.* Taking all the experiments together the percentage is lowered to $82 \%$, which even then is higher than in S. anguicoma.

\section{Conclusion.}

If " outside" water in quantity had been available, probably a higher percentage of pieces of $S$. troglodytes and $S$. anguicoma would have been

\footnotetext{
* It is just possible (but not probable) that one or two of these pieces included tentacles when first cut off.
} 
reared than in tank-water; and probably the same would be true in nature. This consideration notwithstanding, the marked differences which occurred under identical conditions in the four species certainly mean something, and it may be concluded that the regeneration of pieces takes place more readily in the species which lacerate in nature than in those which do not. At the same time those which do not naturally lacerate are able to regenerate from fragments, though to a different degree in different cases. This renders the more remarkable the fact that they do not normally lacerate in the wild state.

\section{EVIDENCE DERIVED FROM THE LITERATURE.}

It is hardly necessary to give a complete summary of the data available in the literature which bear on the subject at issue, for reasons which will appear (note on exceptions, in Section 7). I give, however, a selection of facts extracted from the considerable amount of literature which exists on the subject. Some of these supplement my own results, especially in the cases of Diadumene lucia (where my results are scanty) and Cereus pedunculatus. The other extracts are designed to illustrate the type of observations which have been made by other authors.

Fission, laceration and regeneration in Actinians have been studied by a number of authors-by Carlgren, Dalyell, Andres, Cary, Davis, Child, Parker, Hammatt, Torrey, Hazen, Loeb, and others. Many of the observations of these authors are relevant to the present question, although the aim of their studies has usually been distinct from that of this paper. Several of them, for instance Dalyell, Carlgren, and Davis, have clearly realised that in forms with which they were dealing a stated method of reproduction was characteristic of given species. The data quoted below, from Dalyell, makes this evident, in his case. Carlgren, in his 1904 paper on regeneration, deliberately selected for certain experiments species which do not habitually reproduce asexually, in order to avoid the introduction of complicating factors into his work; and in many other ways it is clear that he is aware of the state of affairs. The present paper, however, is the first study, as far as I know, devoted to the consideration of the specific value of reproductive methods as such.

The observations made in his aquarium by Sir John Dalyell possess great value, and the following data, extracted from his Rare and Remarkable Animals of Scotland, concern us here.

Actinia equina. Specimens were kept in captivity for as long as 13 and 20 years. Dalyell was fully aware that the normal habit of the species is to produce viviparous young; he also observed the production of embryos prior to metamorphosis, but these were rarely liberated by the parent, and such an occurrence was regarded by Dalyell as accidental and 
non-typical. One specimen in his possession for 20 years produced 334 young during that time; another which he kept for over four years produced 200 young in 14 days. The first of these specimens produced further young after Dalyell's death (see Ashworth and Annandale, 1904). In other cases young individuals were reared. One of these first produced viviparous young when between 14 and 15 months old, and by the time it was 4 years old had produced 64 of them. Another lived for nearly 5 years; at 3 years old it had produced 28 young, the first of which had appeared at between 13 and 14 months ; subsequently it produced many more, 7 one night and 15 another. A third produced its first young at a year old, produced 60 in three years, and more afterwards ; this one lived 10 years. A fourth began to breed at 14 months old, and was prolific; two depositions of young containing 60 and 43 respectively; this specimen, a double one, was accidentally torn in half at about six years old, and one half produced further young after this. In this species viviparity has also been observed by many other workers.

Sagartia elegans. Here there is an observation made by Dalyell to the effect that specimens kept by him for three years produced no viviparous young; this confirms my own and Evans's results.

S. troglodytes (the "Actinia explorator" of Dalyell). Dalyell was aware that this species is viviparous, and records the production of over 60 young in a night by two small specimens.

$S$. lacerata. In the case of this species Dalyell showed that laceration is the characteristic mode of reproduction. On page 228 he remarks: "Amidst the numerous embarrassments obstructing the discrimination of species and varieties of the Actinia " (i.e. of Actiniæ), "it is fortunate to meet certain immutable features, so prominent as to distinguish some of them, so definitely from all others, as to leave no liability to error." This remark refers, partly at least, to the habit of laceration. One of Dalyell's specimens produced over 70 young by laceration in the course of a year, and one laceration which was reared began to lacerate itself after nine months, and produced 40 lacerations in 80 days. Specimens were kept for over three years ; no viviparous young were ever observed. Lacerations sometimes achieved tentacles 15 days after the appearance of the basal irregularities which produced them.

Finally, Dalyell realised that among anemones the animal "propagates by two distinct fashions, as seen in different species "- this refers to viviparity and laceration by constriction, other methods (apart from the production of ova) not having come to his notice.

Next we may consider a paper by Davis (1919) on asexual multiplication and regeneration in Diadumene lucia. This paper deals mainly and in detail with the morphological results of fission, but a large amount of material was used by the author, and it emerges clearly from his study 
that longitudinal fission involving the tearing of mouth and throat is a characteristic and frequent occurrence in the species; and the author remarks on page 167 : "There is no suggestion of a division resembling that known as basal fragmentation. Any other method of asexual reproduction than that described above" (i.e. fission), "must be very rare in the adult form of this species." That fission is habitual in the species is confirmed from various quarters, by the observations of Davenport, Hargitt, Hausman, Walton, etc., as well as those of Evans and myself. It has also been suggested that the species can bud and lacerate (Davenport 1903, Hausman 1919), but these suggestions are not, so far as I know, founded upon actual observations, and if they are correct these processes must, as Davis remarks, be quite exceptional.

In 1911 Cary published a paper on pedal laceration in Actinians, giving an account of this occurrence in Cylista leucolena and in three species of Aiptasia (none of these forms is British). Among 1300 specimens of $C$. leucolena examined, 1234 had given rise to lacerations; the same is true of 78 out of 150 specimens of Aiptasia pallida, of 187 out of 220 of $A$. tagetes, and of 20 out of 52 of $A$. annulata. For details reference should be made to the paper.

The observations made by Miss Jessie Nelson, and later by Ashworth and Annandale (1904), and by Evans, on some specimens of Cereus pedunculatus, are interesting in this connection. The specimens in question are 16 in number, and have now been in captivity for some 66 years ; their actual age must be at least 70 years, and may be considerably more. These specimens (referred incorrectly by Ashworth and Annandale to $S$. troglodytes) are still in good health, and during their captivity have produced countless viviparous young, some of which have been reared and have been prolific in their turn, which applies again to the grandchildren. The original specimens are mostly still breeding freely, and have never, so far as I know, produced anything but such young.*

Further papers dealing with asexual reproduction and regeneration are enumerated in the list of literature at the end of this paper, and the case of Metridium is mentioned on page 162. The above examples will serve to illustrate the sort of material which may be gleaned from the literature, and the only other point which need be noted at the moment is that there exist records which contradict the conclusions of this paper ; these are dealt with on page 161 .

* One of the original specimens was removed from the tank containing the others on May 27, 1925; in the 123 days succeeding its isolation it produced 102 young. Since then it has produced none up-to-date (May, 1928). This suggests that it had been fertilised from sperm of another individual before isolation-although no emission of sperm had been seen. Some specimens of the species are undoubtedly hermaphrodite, but it does not follow that it is self-fertilising. 


\section{THE EFFECT OF THE MODE OF REPRODUCTION UPON THE MORPHOLOGY.}

A considerable body of knowledge exists as to the effect of asexual reproduction on the morphology of Actinians, and as to the morphological conditions which follow the regeneration of artificially separated portions of these animals. For details reference must be made first and foremost to the very important papers of Carlgren (1904, 1909, 1909a), and also to that of Davis (1919) above mentioned, as well as those of Cary (1911), Davenport (1903), Hargitt (1914), Parker (1897, 1899), Torrey (1898, 1902), Hammatt (1906), A. F. Dixon (1888), G. Y. and A. F. Dixon (1889 and 1891), Hahn (1905), etc.

The point I wish to make here is that there is quite enough evidence to show that anemones with more or less irregular symmetry (i.e. those which depart from the typical condition possessing 2 siphonoglyphs, 2 pairs of directives, 6 primary pairs of mesenteries, and 6 primary tentacles, all bilaterally arranged) are generally specimens which in one way or another have been produced asexually. These specimens may have a varying number of siphonoglyphs and directives, a number of primary tentacles and mesenteries other than six $(4,5,7,8,9,10,11,12$, 13, 14), and no definite bilateral symmetry. This is the general rule; but it does not imply either (a) that asexually produced specimens are never hexamerous and bilateral, nor that (b) sexually produced specimens are never irregular. Both these conditions do exist, for specific causes. But our knowledge is sufficient to make it a very probable assumption that if, in any given species, a high proportion of the individuals exhibit irregular symmetry, this is a species in which asexual reproduction is frequent. If, in such a case, we have even a few actual records of asexual reproduction, the assumption that it is general becomes still more likely. Conversely, the result of my own and other observations shows that in the case of viviparous species the young are normally symmetrical and hexamerous; so, consequently, are the adults ; and if, in a species whose reproductive habit is not known, the adults are found to be regular and hexamerous, it is probably one in which either viviparity or at least the absence of asexual reproduction is prevalent. There do arise cases in which individuals of sexual origin are irregular; but this can be due to reparation of injured parts and similar causes, and does not affect the general rule. My own study of a wide range of material has shown that the above remarks apply to the species specially dealt with in this paper-i.e. in Sagartia elegans, S. lacerata, S. sphyrodeta, Diadumene lucia, and $D$. cincta, the adult symmetry is often or usually more or less irregular, whereas in S. troglodytes. S. anguicoma, and Cereus 
pedunculatus (viviparous or oviparous forms) the symmetry is normally regular and hexamerous. In this latter connection it may be noted that in a paper published in 1898, Clubb records an anatomical examination of 165 specimens of the viviparous Actinia equina. All of these were hexamerous; and 158 of them were bilaterally symmetrical, with 2 syphonoglyphs and 2 pairs of directives.

\section{REPRODUCTION IN THE BRITISH SPECIES AS A WHOLE.}

I am at present unable to give a complete collection of records of reproduction in British species from the literature, because I am on the eve of departure for a year's research in Australia; but in the following list I give a contribution towards these records, from the observations of Evans and myself. In some cases the data given are merely additions to, or confirmation of, facts already known; in others the data are new. The letters $\mathrm{E}$ and $\mathrm{S}$ indicate whether the observation is due to Evans or myself; and species in which we have seen no reproduction are not included. "Sperm, 2.27 " means " Sperm emitted, February, 1927 "and so on.

Gonactinia prolifera. Transverse fission (S).

Milne-Edwardsia carnea. A young specimen taken from a Ctenophore (Bolina sp.) upon which it was parasitic, in October, 1926, was reared by Miss Delap, of Valencia, and sent to us. We both confirm it as this species, having seen it alive and sufficiently grown for an accurate determination. We have also seen young specimens creeping about stones inhabited by the adult.

Halcampa chrysanthellum. Sperm, 2.27 (S).

Ilyanthus mitchellii. Ova, 26.10.26; 9.27 (E). The ova are extremely large.

Actinia equina. Viviparous young habitual (E and S).

Anemonia sulcata. Longitudinal fission, 25.9.22; 28.4.24; 2.4.25; $1.9 .23(\mathrm{E})$.

Bolocera tuedice. Ova, July, 1925, and in 1926 (E).

Tealia felina. Sperm, 5.11.22. etc. (E).

Bunodactis verrucosa. Viviparous young habitual (E and S). A brood of 27 young (produced under the action of menthol) was seen, 30.5.27 (S), the same individual producing more young later. This specimen and some of its young are illustrated in Text-Fig. 5 .

Anthopleura thallia. Longitudinal fission frequent (E). The prevalent irregular symmetry of this species supports these observations.

Diadumene cincta. Laceration by tearing fairly frequent (E and S).

D. luciar. Longitudinal fission habitual (E and $\mathrm{S})$. 
Aiptasia couchii. Transverse fission, 10.25 (E) ; viviparous young, $8.25(\mathrm{E})$.

Metridium senile. Laceration habitual (E and S). Ova, 4.8.22; sperm and ova at other times (E).

Calliactis parasitica. Sperm, $9.22(\mathrm{E})$.

Adamsia palliata. Ova, 29.10.25, and on several occasions since (E).

Cataphellia brodricii. Viviparous young in quantity from specimens collected at Salcombe and Wembury (Devon) in March and April, 1927. Several adults produced young, the total number of the latter amounting to 231 ; the three largest broods contained respectively 68,85 , and 51 . Since the adults and young are normally regular and hexamerous, it is probable that viviparity is habitual (S). Specimens sent to Edinburgh at the time mentioned produced further young individuals afterwards (E).

Hormathia coronata. Viviparous young, $15.3 .25 ; 7.5 .25 ; 10.6 .25$; $7.4 .27(\mathrm{E})$. The species is normally regular and hexamerous, and there are French records which state that it is viviparous; probably, therefore, it is habitually so.

Paraphellia expansa. Ova probably belonging to this species have been seen (E).

Gephyropsis dohrnii. Laceration, 15.11.25 (E), and at other times (S).

Sagartia elegans. Laceration by tearing habitual (E and $\mathrm{S})$.

S. anguicoma. Sperm, $11.25(\mathrm{E})$.

S. troglodytes. Viviparity habitual (E and S). Sperm, 11.6.22; ova, 9-10, $6.23(\mathrm{E})$, and at other times (E and S).

S. lacerata. Laceration by constriction habitual (E and S).

S. sphyrodeta. Longitudinal fission habitual (E and S).

Cereus pedunculatus. Viviparity habitual (E and S).

Phellia gausapata. Laceration observed in each of 5 specimens; one or two lacerations produced by each (E).

\section{DISCUSSION.}

It has been sought to establish that

(1) In the species selected for study, the deposition of ova may occur in any of them (except that in Cereus pedunculatus the ova normally, and perhaps always, develop within the cœlenteron of the parent).

(2) Apart from this, there are two principal methods of propagation in these species, viviparity and asexual reproduction; and only one of these methods normally occurs within a single species.

(3) In the forms which reproduce asexually, only one out of three possible methods (total longitudinal fission, laceration by constriction, or laceration by tearing) normally occurs in any one species. 
Can the above statements be regarded as proved ? In this connection the following points may be noted.

(1) It is a striking fact that there is not, in my experiments, a single exception of any kind to the rules postulated. The same applies to the observations of Evans, and to my own general experience of living anemones, which has spread over some fourteen years. This distinctly enhances the results. The most difficult point to establish is the negative observation that certain species do not reproduce asexually ; but since asexual reproduction occurs at any time of the year, and fairly freely where it does take place, there should have been at least some exceptions if a negative conclusion were incorrect.

(2) There are other series of data available beyond the experiments, which confirm the above results.

$A$. Observations by various workers recorded in the literature. It so happens that in some instances where my own results are scanty, the gap can be filled either from the literature or from Evans' observations.

$B$. There are data available relating to the morphology of considerable numbers of specimens of many of the species concerned, which add confirmation to the experimental results.

(3) For the above reasons I believe that, although my experiments taken alone would be insufficient to prove the case, when all the available data are taken into account, the conclusions outlined above are justified. Moreover, I have reason to think that the numbers yielded by my experiments understate the case rather than otherwise, since the processes observed went on rather more slowly under the Plymouth conditions than has been the case with many of the specimens in Evans' aquarium.

The question of exceptions must be next considered. I do not wish to maintain that in any species such never occur; they may well do so, even though they have not come under my notice; but even if they do, the general contention is not invalidated. In species which have not been specially studied here, moreover, it may be true that different conditions occur, and that combinations not represented in those here selected are present. It is quite possible that just as in morphology it is found that some species are stable and others are unstable, so in the matter of reproduction it may be true that some species (such as those investigated) are stable or almost stable, others more variable. I suspect that Metridium may be somewhat variable in this respect, although laceration is certainly its prevalent method. Agair, in Aiptasia couchii, 
although we do not know enough about the species to be sure what are its normal habits, it appears to be established that the species is viviparous and that it also undergoes, at times, a curious form of transverse fission.

Nor must the possibility be forgotten that within the same species the method of reproduction may vary with locality. I am not aware that this applies to any of the British species within the British area, but it may apply, for instance, to their Norwegian or Mediterranean representatives. In the case of Actinia equina, Gravier has found that the species is still viviparous at the island of S. Thomé, near the Equator. In Sagartia troglodytes, however, the viviparous habit has not been observed by Carlgren in Scandinavian waters (this species is in any case oviparous as well), although of course it may occur. Carlgren's observations on $S$. troglodytes confirm my own, that it does not reproduce asexually, and the same applies to $S$. viduata, a northern species closely allied to S. anguicoma.

There are a number of records in the literature which definitely contradict my observations. It is very difficult to tell whether these have any serious bearing on the question, because frequently either sufficient precision is lacking in the records, or they apply to isolated instances only. It must be remembered that the phenomena exhibited by Actinians have not always been understood at all clearly. When, for instance, we are told that in some species budding has been observed, it is much more likely that what was actually seen was either a subsidiary tuft of tentacles (sometimes including a disc and throat as well) on the side of the anemone, produced as the result of a small wound, or as the consequence of the regeneration of an atypical laceration; or some other similar phenomenon. Such formations resulting from wounds certainly do occur, and have nothing to do with asexual reproduction. Some records of " buds" are due to a regenerating laceration which has not been fully detached from the parent. True budding is probably very rare among Actinians, if it occurs at all. Again, at one time it was generally assumed that double-headed anemones, or specimens with two bases, were necessarily stages in fission. Carlgren and others have shown that permanent double-monsters can originate from arrested and incomplete fission; but that many of them are double from an early embryonic stage, or arise from some other reason, and their condition has nothing to do with ordinary asexual reproduction.

Further, in the early days an isolated record of the production of viviparous young, in the species in which we know that they do not normally occur, might well apply to basal fragments which had not been noticed until they had formed tentacles. When, as was often the case, the actual birth of the young was not witnessed, this is the probable 
explanation, and I know of one instance in which it actually occurred. In other cases records are rendered valueless because we cannot be certain that the specimens under observation really belonged to the species to which they were assigned; several species of Sagartia live in the same localities and have often been confused one with another. For the above reasons, although I am aware, to give instances, that viviparity has been recorded in S. elegans (Gosse 1860, pp. 46 and 71), that laceration has been recorded in Actinia equina (Landauer 1924), Cereus pedunculatus and Bunodactis gemmacea (Andres 1881), and so on, I am confident that the majority of such records are either mistakes, or that they refer to the results of injury, to double individuals, or to similar conditions. Some of them, no doubt, refer to genuine exceptions, but there is no evidence to show that these exist in sufficient amount to invalidate in any way the conclusions of this paper. Such records for the genus Sagartia are but few.

The case of Metridium is worthy of a little further attention, since much research has centred round it. Papers dealing partly or entirely with Metridium have been published by Carlgren (1904, 1909), Verrill (1922), McMurrich (1901, 1911), Hausding (1914), Parker (1897, 1899), Torrey (1898, 1902), Hammatt (1906), G. Y. and A. F. Dixon (1891), Hahn (1905), etc. Carlgren, Parker, Torrey, and Hahn especially have studied the influence of asexual reproduction on the morphology, among them giving many details of variation in siphonoglyphs, number of perfect mesenteries, and general symmetry, and dealing with the question of double-monsters, etc. Torrey (1902) emphasises that although fission and budding occur in the species, neither of these has more than a trifling influence on the number of individuals, since laceration is frequent, rapid, and universal. Among 2662 individuals, less than $2.5 \%$ were suspected of fission or budding, and if the origin of the so-called " fission " and "budding" could be fully studied it would doubtless be found that many or most of the instances were really due to double-monsters, injuries, etc. Double specimens are normally permanently double and the halves do not separate. Whether fission of the type found in Sagartia sphyrodeta occurs at all in Metridium is doubtful. Consequently, although there may be more variation in the reproductive processes here than in other cases, there is certainly less than might at first sight appear. (The above remarks refer indiscriminately to Metridium senile, $M$. fimbriatum, and $M$. marginatum; it is held by some authors that these are all the same, by others that they are not. The question is not finally soluble at the moment.)

Lastly, I would like to make a comment on the situation; but wish to make it quite clear that the following remarks make no claim to 
represent a discussion of the species-problem in general. I hope to discuss this problem at a later date; but for the moment I am giving an indication of the sense in which the word "species " is here used, in order that the facts concerning methods of reproduction as specific characters may be fitted into their place with relation to our existing knowledge of species.

There exists, as is well known, an unfortunate division of zoologists into systematic and general workers. Systematic work is regarded, not without reason, by the ordinary zoologist, as at the best a necessary evil, and it is hardly possible to mention the word "species" without causing an unfavourable reaction in one's audience; the very word conjures up visions of dullness. For this state of affairs the systematists cannot be held guiltless, since their work represents, only too often, a purely academic study of certain aspects of organisms, and is divorced from any general interest in the field of zoology as a whole. On the other hand, it is unfortunate that the question of species receives as little attention as it does from zoologists in general. The subject of evolution is one of the central problems of biology, and it is a problem which is intimately bound up with that of species. It will hardly be denied by anyone that work which sheds light upon the question of evolution is a live issue. At the present time, when experimental methods of research are so much to the fore, there is an excellent opportunity for a fresh attack upon the species-problem, from an angle distinct from the classical one. It is not enough to "leave it to the systematists," since this will not lead to any advance in our knowledge; the field must be explored by biologists with general knowledge and interests.

If, then, we are to approach the problem along new lines, one of the steps which must first be taken is this, that species must be studied intensively, and everything about them must be taken into account. Not only must we know that $\mathrm{A}$ differs from $\mathrm{B}$ in the possession of a different number of hairs on its legs, but we must also know the whole of its morphology, its life-history and habits, its methods of reproduction, and whether it possesses distinctive physiological characteristics unlike those of B. When this has been done we shall at least know more about the potentialities of species than is at present the case.

At this point there arises the question "What is a species?" This is a matter of definition too involved for detailed discussion in the present paper, but it will be advisable to give some indication of the sense in which the term is here employed.

The Actinians which have been specially studied here present a case in which, despite the general belief to the contrary, it is possible to recognise the species (from living specimens) quite distinctly by taking into account morphology, markings, and colouration; and no specimen 
comes to hand of which one cannot say "this anemone belongs to such-and-such a species, and it is clearly different from any other kind of anemone." So much is this the case, that it is often possible to identify an anemone from a detached fragment of its basal margin.

For the purposes of the present stage of this discussion, therefore, the word "species" may be regarded, in the first place, as a term covering all existing specimens of any animal which is not of the same kind as any other animal ; the criteria of distinction being a series of differences which are visibly expressed throughout the entire morphology. But since the factor of time must also be considered, this definition requires the qualification that a species now living also includes many individuals which are extinct, and many which are yet to come. Its limits in time lie between

(a) The time when the animal type in question first became recognisably distinct from any other.*

(b) The time when this same type, by splitting up into others, or by becoming extinct, will cease to exist as such.

Hence, it is clear that a species, although it may persist for a long time, is transitory. Moreover, if it is one which is to split up ultimately into others, there will be a period at the beginning and another at the end of its history during which it will be difficult to distinguish it from parallel or derived forms. Consequently, the limits of a species in time can never be precisely fixed, although its morphological limits for a certain period of its history may be sharply marked. It may be true, moreover, that at the present time a number of species are not in the phase of evolution during which they are recognisably distinct, as in the case of the Actinians in question, but are in a state of flux. If such forms exist, one would expect to find groups of forms, evidently allied, among which races (linked perhaps by numerous hybrids) can be distinguished with more or less accuracy, but among which the species cannot be determined with the degree of precision which is practicable among the anemones. I feel that such an explanation may account, for instance, for the state of affairs which prevails in the genus Dactylorchis, a group of plants which I have studied somewhat extensively in the field. If, therefore, there are cases in which it is possible accurately to determine specific limits, and others in which it is not possible; and if in any case the limits of a species in time are not sharply marked; it is evident that the conception of a species is at present lacking in precision. But in the following paragraphs the word may be understood to mean, as nearly

* By " recognisably distinct " is meant " distinguished by a series of differences which are visibly expressed throughout the morphology"; i.e. recognisably distinct as an animal type from any other animal type. In other words, although a red animal is " recognisably distinct" from a black one (and the difference may depend upon a Mendelian factor), this does not necessarily mean that the two are specifically distinct. 
as the above qualifications will allow, an animal type which is different from all other animal types.

Having explained the interpretation to be placed upon the word "species" for the purpose of this discussion, it may next be pointed out that, in the methods of reproduction which have been studied in these anemones, we have a criterion for specific distinction of a nature different from the usual morphological standard. It is evident that in dealing with a sharp distinction between a species which does, and another which does not, habitually reproduce asexually, we are dealing with a marked difference between the physiological constitutions of the forms in question. The fact that any species can regenerate from artificially separated fragments merely renders more striking the apparently complete abstinence of certain species from doing so. Now, in the species in question there is no doubt about the morphological distinctions between them; but we can hardly speak of a reproductive method as "morphological." It is true that morphological distinctions are the expression of different series of physiological processes, and that the "morphological" and the "physiological" are interdependent, and merge into one another when philosophically considered; but for ordinary purposes of terminology it is necessary to draw a line between the two, and a method of reproduction must lie on the physiological side of that line.

This raises the question of "physiological species" in general. In this connection it may be noted that in the higher animals (e.g. the mammals) the morphological differences between species may be considerable, whereas marked physiological differences of a grade comparable to the differences in reproductive physiology exhibited by the anemones, are not present. The interest of the anemones lies in the fact that among them there may exist side by side a slight degree of morphological distinction between two species, accompanied by a very marked physiological difference. If, in this respect, it is true that the anemones represent a stage intermediate between the highest and the lowest animals (as indeed from general considerations might be anticipated), we should expect to find that on a still lower grade there might be morphological identity between species which would then be distinguishable only by physiological tests; and this state of affairs appears to be realised, for instance, in the bacteria and in the moulds. To such cases as these last, the term "physiological species" may very appropriately be applied; but it should be remembered that such species are of the same essential nature as those which occur among anemones or mammals, whether the criteria which most readily distinguish them be morphological or physiological. In other words, so long as a species is understood in the sense of this discussion, it is immaterial whether the adjective 
applied to it be "morphological" or "physiological." It follows from this, that the word "species" should not be applied to cases in which it is possible, within the limits of a single species (in the accepted sense), to distinguish groups of individuals (e.g. blood-groups) which exhibit different physiological reactions of certain kinds. Such differences as these (which can be paralleled on the morphological side) do not necessarily indicate specific difference at all. It may be that some of them are the forerunners of far-reaching changes which will in time differentiate one species into more than one; but until such differentiation has taken place these groups cannot validly be termed species.

The addition of the bacteria, etc., to the list of organisms amongst which species can be recognised, involves the emendation of the definition of a species given below, to the effect that the criteria which distinguish organisms of one kind from those of another may be physiological instead of morphological.

In conclusion it may be noted that the case of the Actinians is not an isolated one. In Ascidians, as Berrill (1928) has shown, species may be distinguished according to whether or not they have a tadpole-stage in their development. In regeneration among invertebrates, distinct methods of behaviour after injury, characteristic of species, are probably widespread, as demonstrated, for instance, by the work of Nusbaum and Oxner on Lineids. In the anemones themselves, there are specific differences in the power with which the base adheres to foreign substances; in the quality and amount of mucus which the animal secretes; and in its irritability - e.g. in the readiness with which it will shoot forth acontia when provoked. These last-quoted cases, however, are much less sharp and less easily measurable than the methods of reproduction ; and they may vary very considerably from one individual to another, and according to the type of environment which an individual has inhabited, prior to collection. They are, in fact, differences of tendency rather than absolute distinctions such as method of reproduction, mode of early development, or behaviour during regeneration.

\section{SUMMARY.}

1. Eight species of Actinians (enumerated on p. 148) have been specially studied with regard to their reproductive processes.

2. Among these forms five methods of reproduction occur-longitudinal fission; laceration by tearing; laceration by constriction; production of young viviparously; deposition of ova.

3. Deposition of ova may co-exist with any other method, except perhaps in certain viviparous forms. 
4. Apart from this, one method only prevails in any one of the selected species-

A. Longitudinal fission in Sagartia sphyrodeta and Diadumene lucice.

B. Laceration by tearing in Sagartia elegans and Diadumene cincta.

C. Laceration by constriction in Sagartia lacerata.

D. Viviparity in Sagartia troglodytes and Cereus pedunculatus.

5. In Sagartia anguicoma neither viviparity nor asexual reproduction occurs.

6. The viviparous forms studied do not reproduce asexually; nor are those which reproduce asexually viviparous.

7. In the experiments and observations of the author and of W. E. Evans, no exceptions to the above statements occurred. The question of exceptions is discussed on page 161 .

8. Four of the above species were selected for regeneration experiments. Pieces were cut off from the margin of the base in each (artificia) laceration).

9. In Sagartia elegans (which lacerates naturally) it was found that nearly $100 \%$ of such pieces would regenerate easily; in S. lacerata the same was true in the best experiment.

10. In Sagartia troglodytes (which does not lacerate naturally) only two pieces out of 76 regenerated fully, and the regenerative ability of the species appeared to be weak. In $S$. anguicoma, however, the percentage of pieces which regenerated fully (and did so strongly) was very much higher, though not reaching that of S. elegans.

11. Regeneration was probably more rapid, in the main, in the species which lacerate naturally than in the others.

12. It is maintained that sharp distinctions between species, such as those mentioned above, are of interest from the point of view of the general problem of species.

\section{LITERATURE.}

Andres, A., 1881. Intorno alla scissiparità delle attinie. Mitt. Zool. Stat. Neapel, Leipzig, 3, pp. 124-148; 1 pl.

Ashworth, J. H., and Annandale, N., 1904. Observations on some aged specimens of Sagartia troglodytes, and on the duration of life in Cœlenterates. Proc. Roy. Soc., Edinburgh, 25, pp. 295-308.

BerriLl, N. J., 1928. The identification and validity of certain species of Ascidians. J. Mar. Biol. Assoc., Plymouth, (N.S.) 15, pp. 159 175 ; text-illust. 
Blochmann, F., and Hilger, C., 1888. Über Gonactinia prolifera Sars, eine durch Quertheilung sich vermehrende Actinie. Morph. Jahrb., Leipzig, 13, pp. 385-401 ; 2 pls.

Boнn, G., 1908. Scissiparité et autotomie chez les Actinies. C.R. Soc. Biol., Paris, 1908, v, 1, pp. 936-939.

Broderick, F. N., 1860. On the transverse fission of Aiptasia couchii. Zoologist, London, 18, pp. 6911, 6912.

Carlgren, O., 1893. Studien über Nordische Actinien. K. Svenska Vetensk. Akad. Handl., Stockholm, 25, 10, pp. 1-148; 10 pls. ; text-illust.

Carlgren, O., 1904. Studien über Regenerations- und Regulations -erscheinungen, Pt. 1. K. Svenska Vetensk. Akad. Handl., Stockholm, 37, 8, pp. 1-105; 11 pls. ; text-illust.

Carlgren, O., 1904-5. Kurze Mitteilungen über Anthozoen, 1-4. Zool. Anz., Leipzig, 27, pp. 534-549 ; text-illust. ; ibid., 28, pp. 510-519; text-illust.

Carlaren, O., 1909. Studien über Regenerations- und Regulations -erscheinungen, Pt. 2. K. Svenska Vetensk, Akad. Handl., Stockholm, 43, 9, pp. 1-48; 4 pls. ; text-illust.

Carlgren, O., 1909a. Studien über Regenerations- und Regulations -erscheinungen, Pt. 3. Ibid., 44, 2, pp. 1-44; 3 pls.; text-illust.

Carlgren, O., 1925. Zur Regeneration der Actiniarien. Z. Morph. Ökol. Tiere, Berlin, 5, pp. 150-154.

CARY, L. R., 1911. A study of pedal laceration in Actinians. Biol. Bull. Woods Hole, 20, pp. 81-108 ; 4 pls. ; text-illust.

Child, C. M., 1904. Form-regulation in Cœlentera and Turbellaria. Smithson. Misc. Coll., Washington, 45, pp. 134-143.

Child, C. M., 1908. Regulation of Harenactis attenuata in altered environment. Biol. Bull. Woods Hole, 16, pp. 1-17; text-illust.

Child, C. M., 1909. Factors of form regulation in Harenactis attenuata, I-III. J. Exp. Zool., Philadelphia, 6, p. 471; 7, p. 65 ; 7, p. 353.

ChILd, C. M., 1909a. Experimental control of certain regulatory processes in Harenactis attenuata. Biol. Bull. Woods Hole, 16, pp. 47-53; text-illust.

Clubb, J. A., 1898. Actinological Studies, 1. The mesenteries and œsophageal grooves of Actinia equina. Linn. Proc, L'pool. Biol. Soc., Liverpool, 12; pp. 300-311; Pl. 20. 
Cotronei, G., 1924. Doppie formazioni, scissiparità e rigenerazione nelle Attinie. Pubbl. Staz. Zool. Napoli, Milano, 5, pp. 199-273 ; 1 pl. ; text-illust.

Dalyell, J. G., 1847-48. Rare and remarkable animals of Scotland . . . with . . observations on their nature. Lond. Pls., col.

Davenport, G. C., 1900. Variation in the sea-anemone Sagartia lucia. Science, New York, (N.S.) 11, p. 253.

Davenport, G. C., 1903. Variation in the number of stripes on the seaanemone Sagartia lucia Verrill. Parker, G. H., Mark Anniversary Volume, New York, 1903, pp. 139-146; Pl. 10.

Davis, D. W., 1909. Fission and regeneration in Sagartia lucia. Science, New York, (N.S.), 29, p. 714.

Davis, D. W., 1919. Asexual multiplication and regeneration in Sagartia lucia Verrill. J. Exp. Zool., Philadelphia, 28, p. 161.

Dixon, A. F., 1888. On the arrangement of the mesenteries in the genus Sagartia, Gosse. Sci. Proc. R. Dublin Soc., Dublin (N.S.), 6, pp. 136-142; 2 pls.

Dixon, G. Y., AND A. F., 1889. Notes on Bunodes thallia, Bunodes verrucosa, and Teatia crassicornis. Ibid., (N.S.) 6, pp. 310-326; Pls. IV, V.

Dixon, G. Y., AND A. F., 1891. Report on the marine invertebrate fauna near Dublin. Proc. R. Irish Acad., Dublin, (3) 2, pp. $19-33$.

Evans, W. E., 1924. On the identity of the sea-anemone Actinia elegans Dalyell. Scot. Nat., Edinburgh, 1924, pp. 121-125.

Evans, W. E., 1924a. The occurrence in the Forth of the sea-anemone Sagartia pallida (Holdsw.), with remarks on its anatomy, reproduction, and affinities. Ibid., 1924, pp. 185-188.

Evans, W. E., 1925. On the supposed occurrence in Scotland of the seaanemone Hormathia coronata (Gosse), with notes on its reproduction, etc. Ibid., 1925, pp. 89-94.

Gemmill, J. F., 1919. The development of the mesenteries in the Actinian Urticina crassicornis. Proc. Zool. Soc., London, 1919, pp. $453-457$; text-illust.

Gemmill, J. F., 1920. The development of the sea-anemones Metridium dianthus (Ellis) and Adamsia palliata (Bohad.). Philos. Trans., London, B, 209, pp. 351-375; Pls. LVIII-LX. 
Gosse, P. H., 1860. Actinologia Britannica: A history of the British sea-anemones and corals, etc,. London, 1860. (Note; published in parts as follows: pp. 1-160, 1858; pp. 161-352, and Preface, 1859 ; pp. 353-362, 1860.) Pp. $x \mathrm{l}+362$; 11 pls., col.

Gravier, C. J., 1916. Sur l'incubation chez l'Actinia equina L. a l'Ile de San Thomé (Golfe de Guinée). C. R. Acad. Sci., Paris, 162, pp. 986-988.

Hahn, C. W., 1905. Dimorphism and regeneration in Metridium. J. Exp. Zool., Philadelphia, 11, p. 225.

Hамматт, M. L., 1906. Reproduction of Metridium marginatum by fragmental fission. Amer. Nat., Boston, 40, pp. 583-591; 2 pls. in text.

Hargitt, C. W., 1914. The Anthozoa of the Woods Hole Region. Bull. U.S. Bureau Fisheries, Washington, 32, pp. 225-254; pls., col. ; text-illust.

Hausding, B., 1914. Studien über Actinoloba (Metridium) dianthus. Arch. Ent. Mech, Org., Leipzig, 38, pp. 49-135; text-illust.

Hausmann, L. A., 1919. The orange-striped anemone (Sagartia lucia Verrill) : an ecological study. Biol. Bull. Woods Hole, 37, pp. 363$370 ; 1 \mathrm{pl}$.

Hazen, A. P., 1902. The regeneration of an œsophagus in the anemone Sagartia lucia. Arch. Ent. Mech. Org., Leipzig, 14, pp. 592-599; Pl. 31.

Hazen, A. P., 1903. Regeneration in the anemone Sagartia luciar. Ibid., 16 , pp. $365-376$; text-illust.

Holdsworth, E. W. H., 1860. On the transverse fission of Aiptasia couchii. Zoologist, London, 18, pp. 6945, 6946.

Kerb, H., 1913. Studien über die ungeschlechtliche Fortpflanzung der Gonactinia prolifera Sars. Bergens Mus. Aarb, Bergen, 1913, No. 3, pp. 1-14; text-illust.

Landauer, W., 1924. Laceration, Knospung und Heteromorphose bei Actinia equina L. Z. Morph. Okol. Tiere, Berlin, 3, pp. 177-187 ; text-illust., col.

Loeb, J., 1905. Studies in general physiology. Decennial publ. Univ., Chicago, 2nd series, 15, Pts. 1, 2.

McMurrich, J. P., 1901. Report on the Hexactiniæ of the Columbia University Expedition to Puget Sound, etc. Ann. N.Y. Acad. Sci., New York, 14, pp. 1-52; 3 pl., col. ; text-illust. 
Matthai, G., 1926. Colony-formation in Astræid Corals. Philos. Trans., London, B, 214, pp. 313-367 ; 5 pls. ; text-illust.

Nusbaum, J., and Oxner, M., 1910. Studien über Regeneration der Nermertinen. Arch. Entw. Mech., Leipzig, 30, I, pp. 73-132.

Nusbaum, J., ANd Oxner, M., 1911. Weitere Studien über Regeneration der Nemertinen. Ibid., 32, pp. 349-396.

Nusbaum, J., and Oxner, M., 1912. Fortgesetzte Studien über Regeneration der Nemertinen. Ibid., 35, pp. 236-308.

OKADA, Y. K., 1926. Aktinienregeneration aus abgeworfenen Tentakeln. Arch. Entw. Mech., Berlin, 108, pp. 482-486; text-illust.

Parker, G: H., 1897. The mesenteries and siphonoglyphs in Metridium marginatum Milne-Edwards. Bull. Mus. Comp. Zool. Harv., Cambridge, Mass., 30, pp. 259-272; 1 pl.

Parker, G. H., 1899. Longitudinal fission in Metridium marginatum Milne-Edwards. Ibid., 35, pp. 43-55; 3 pls.

Parker, G. H., 1902. Notes on the dispersal of Sagartia lucia Verrill. Amer. Nat., Boston, 36, pp. 491-493.

Provho, H., 1891. Observations sur la Gonactinia prolifera (Sars), etc. Arch. Zool. exp. gén., Paris, (2) 9, pp. 247-254 ; Pl. 9.

Stephenson, T. A., 1920-22. On the classification of Actiniaria. I. Forms with acontia and forms with a mesoglœal sphincter. Quart. J. Micr. Sci., London, 64, 1920, pp. 425-574 ; 1 pl. ; text-illust. II. Consideration of the whole group and its relationships, with special reference to forms not treated in Pt. I. Ibid., 65, 1921, pp. 493-576 ; text-illust. III. Definitions connected with the forms dealt with in Pt. II. Ibid., 66, 1922, pp. 247-319.

Stephenson , T. A., 1928. The British Sea-anemones. Vol. I. London, Ray Society ; 14 pls., col. ; text-illust.

Torrey, H. B., 1898. Observations on monogenesis in Metridium. Proc. Calif. Acad. Sci., San Francisco, Zool., (3) 1, pp. 345-360; 1 pl.

Torrey, H. B., 1902. Anemones, with discussion of variation in Metridium. Proc. Wash. Acad. Sci., Washington, 4, pp. 373-410 ; 2 pls. ; text-illust.

Torrey, H. B., 1904. On the habits and reactions of Sagartia davisi. Biol. Bull. Woods Hole, 6, pp. 203-216.

Torrey, H. B., ANd Mery, J. R., 1904. Regeneration and non-sexual reproduction in Sagartia davisi. Univ. Calif. Pub. Zool., Berkeley, 1, pp. 211-226; text-illust. 
Vallentin, R., 1896. Some notes on the pelagic life occurring in the sea near Falmouth, with fauna notes of the district. J. Roy. Instn. Cornwall, Truro, 12, pp. 204-241.

Vallentin, R., 1896a. Some remarks on the pelagic life occurring in and near Falmouth Harbour, with additions to the fauna of the district for 1894. Ibid., 13, pp. 43-51.

Walton, C. L., 1908. Notes on some Sagartiidæ and Zoanthidæ from Plymouth. J. Mar. Biol. Assoc., Plymouth, 8, pp. 207-214.

Weilu, R., 1926. Observations sur le bourgeonnement des Actinies. Ibid, 51, pp. 273-279; text-illust. 